\title{
The awareness level of the parents about the benefits of the physical education lesson in secondary grade of the primary education schools
}

\author{
Burak Taş ${ }^{1}$, Hakan Akdeniz ${ }^{2, a}$, Gülşah Sekban ${ }^{1}$, and Fatmanur Öztürk ${ }^{1}$ \\ ${ }^{1}$ Department of Physical Education and Sport Teaching, Sports Science Faculty, Kocaeli University, \\ Kocaeli, Turkey \\ ${ }^{2}$ Department of Physical Education and Sports Teachership, Institute of Educational Sciences, Sakarya \\ University, Sakarya, Turkey
}

\begin{abstract}
This study is intended to determine the awareness level of the parents on the benefits of the Physical Education Course in the Secondary Grade of the Primary Education Schools. The sample of this study consists of 130 parents whose children studied at Şehit Ümit Balkan Secondary School in the District of İzmit in the Province of Kocaeli in the 2015-2016 academic year. The study is carried out by using the survey method for the purpose of collecting any and all data. The data collected is calculated through package program SPSS 17.0. In respect of the analysis of the data, the frequency $(\mathrm{N})$ and percentage (\%) values which are the descriptive statistics for all of the independent variables are determined primarily. Then, T-Test is utilized to determine the difference between the binary variables. The level of significance is considered as $p<0.05$, and any required results have been specified accordingly. In consequence of the study carried out, no significant difference at the level of $\mathrm{P}>0,05$ is determined between the awareness level of the parents regarding the variable of gender concerning the benefits of the physical education course in the secondary grade of the primary education schools Keywords: Secondary Grade of the Primary Education, Physical Education, Awareness
\end{abstract}

\section{Introduction}

There is the human at the starting point of the education and also at the heart of the short and long termed targets. In this sense, the sport as a part of the education should be considered so as to contribute to the integrity and the whole personality of the human for social health, rest, and peace [8].

\footnotetext{
${ }^{\text {a } C o r r e s p o n d i n g ~ a u t h o r: ~ h a k a n a k d e n i z @ g m a i l . c o m ~}$
} 
These merits that the human naturally has and emerges by the sport and improves reflect his/her daily life as well. In this regard, the sport is a significant tool of the values education. Physical education is based on the necessities of the individual. The movement is accepted as the most basic requirement. Physical activity is essential to living. The stable modern life makes the physical education more relevant within this context. The physical education is an inseparable part of the general training [8].

The primary goal of the physical education and the sport that are the significant parts of the general education is to help for the student to maximize movement capacity by training with moves, viz the physical activities. The other purpose is also to contribute to maximizing the physical, mental, social and emotional developments of children. [17] Moreover, the physical training is necessary regarding using the free time actively, influencing the health positively, developing the collaboration abilities and increasing the self-confidence of the individuals.

While the parents encourage their children for the sport to present a good family example and improve the school success, they spent both the money and the time. In other words, the parents positively support the participation of the children to the sport by paying the admission charge, buying pieces of equipment and being all ears for the game and applications of the children. That is to say, the parents create opportunities for children to be comfortable in the sports environment and are untroubled by the family resources spent as well as they organize the family budget so as to support the participation of their children in the sport [13].

In our country, in primary schools, the 1st-2nd-3rd and 4th classes are called as the First Grade, and the 5th-6th-7th and 8th classes are called as the Second Grade. The first social institution that provides individuals to recognize the physical education and the world of sport is the family. This effect of the family on socialization determines whether the child to join in with the physical training and sports activities and in what way she/he does if she/he enters. The attitude of the parents on this subject is almost the most decisive factor concerning the decision of the children on participation [9]. It is important regarding the future of our sport that to improve the basic education skills of the children, find the successful athletes by being determined their abilities and raise them. Therefore, the parents should believe all the benefits of the sport and place importance on the school-family cooperation. In brief, the parents need to have a sports culture for educating their children about this issue. The parents who have enough information will encourage their children to the sport in the healthiest manner and support them as well [4]. Our schools have important missions about being generalized, endeared and promoted the physical education and sport. There can be created a large base for the individual school and mass sport if the sports love is started in the family such as the basic education and reinforced by supporting in school [5].

In the education field, the 'parent' word is defined as the person who follows the works about the student and is responsible for his/her each kind of behavior and attitude. The parents need to be at a certain awareness level for being the physical training lesson in schools beneficial.

The awareness is a learnable skill. The awareness is a competence to be able to look at the happenings and daily events without being prejudiced by our previous experiences, thoughts, and beliefs [11].

This study is conducted to determine the awareness level of the parents on the benefits of the physical training lesson for children in Secondary Grade of the Primary Education School.

\section{Material and method}

\subsection{Research group}

The population is composed of the parents of the children who study in Şehit Ümit Balkan Secondary School in the 2015-2016 academic year in İzmit District of Kocaeli Province. The working group of the research consists of the parents joined accidentally. It is reached totally 130 parents that 94 of them are women and 36 of them are the men. 


\subsection{Data collection tools}

The survey that is created by receiving the opinions of Prof. Dr. Semra Ünal is used as the data collection tool. The survey entirely has two parts. The first part consists of 7 questions necessitate the demographic information.

The second part has 33 questions that reveal the awareness level of the parents about the benefits of the physical training lesson for children in Secondary Grade of the Primary Education School. The quartet rating scale is used for the questions asked in the second part. These are the following statements; 'Strongly Agree' 'Partly Agree' 'Barely Agree' and 'Disagree.'

Below intervals are considered when being evaluated the arithmetic means of the opinions obtained under the survey.

\begin{tabular}{cclcc}
\hline Weight Given & Alternatives & \multicolumn{1}{c}{ Limit } & Degree \\
\hline 1 & Strongly Agree & 4 & $(107,25-132)$ & High \\
2 & Partly Agree & 3,24 & $(82,5-106,92)$ & Middle \\
3 & Barely Agree & 2,49 & $(57,75-82,17)$ & Enough \\
4 & Disagree & 1,74 & $(33-57,42)$ & Low \\
\hline
\end{tabular}

\subsection{Collecting the data}

The data was collected in Şehit Ümit Balkan Secondary School in 2015-2016 academic year. 280 parents among from 551 ones received the survey, and entirely 130 of these receivers sent the questionnaire back.

\subsection{Analyzing the data}

SPSS 17.0 packaged software is used to analyze this research reviews the awareness levels of the parents about the benefits of the physical training lesson in Secondary Grade of the Primary Education School.

Firstly the frequency $(\mathrm{N})$ and percentage (\%) values that are the descriptor statistics for all independent variables are revealed for being analyzed the data. Later on, the T-Test is used to specify the difference between the binary variables. The significance level is accepted as $\mathrm{p}<0.05$, and the required results are stated.

\section{Findings}

As is seen in Table 1, 72,3\%of the parents are the women, $27,7 \%$ are the men. $6,2 \%$ of the parents are in 20-25 age range, $6,9 \%$ of them are in $25-30$ age range, $35,4 \%$ of them in $30-35$ age range and finally $51,5 \%$ of them are 36 age and older. $65,4 \%$ of the attendees answered the 'Degree' question as a mother, $25,4 \%$ of them answered this question as the father, $6,2 \%$ of them answered as the brother or sister and 3,1\% answered as the others. $0,8 \%$ of the parents responded 'Your Education Status' question as the literate, 27,7\% of them responded as primary school, $24,6 \%$ of them responded as the secondary school, $28,5 \%$ of them answered as the high school and equivalents, $8,5 \%$ of them graduated from the college, $7,7 \%$ of them are bachelors, and $2,3 \%$ of the responded as the other. $6,9 \%$ of the parents are unemployed, $10 \%$ of them are self-employed, $17,7 \%$ of them are the employees, $4,6 \%$ of them are artisans, $6,2 \%$ of them are soldiers, policemen, and officers, 50,8\% of them are housewives, and 3,8\% of these attendees are retired. 
Table 1. The frequency and percentage values of the demographic information of attendees

\begin{tabular}{|c|c|c|c|}
\hline Variables & & $\mathrm{f}$ & $\%$ \\
\hline \multirow{3}{*}{ Gender } & Female & 94 & 72,3 \\
\hline & Male & 36 & 27,7 \\
\hline & Total & 130 & 100 \\
\hline \multirow{5}{*}{ Age } & $20-25$ & 8 & 6,2 \\
\hline & $25-30$ & 9 & 6,9 \\
\hline & $30-35$ & 46 & 35,4 \\
\hline & 36 and older & 67 & 51,5 \\
\hline & Total & 130 & 100 \\
\hline \multirow{5}{*}{$\begin{array}{l}\text { Your degree as the parent to the student } \\
\text { (Degree) }\end{array}$} & Mother & 85 & 65,4 \\
\hline & Father & 33 & 25,4 \\
\hline & Brother or Sister & 8 & 6,2 \\
\hline & Other & 4 & 3,1 \\
\hline & Total & 130 & 100 \\
\hline \multirow{8}{*}{ Your Educational Status } & Literate & 1 & 0,8 \\
\hline & Primary School & 36 & 27,7 \\
\hline & Secondary School & 32 & 24,6 \\
\hline & High Sch. and Equivalents & 37 & 28,5 \\
\hline & College & 11 & 8,5 \\
\hline & Undergraduate & 10 & 7,7 \\
\hline & Other & 3 & 2,3 \\
\hline & Total & 130 & 100 \\
\hline \multirow{8}{*}{ Your Job } & Unemployed & 9 & 6,9 \\
\hline & Self-Employment & 13 & 10 \\
\hline & Employee & 23 & 17,7 \\
\hline & Artisan & 6 & 4,6 \\
\hline & Soldier-Police-Officer & 8 & 6,2 \\
\hline & Housewife & 66 & 50,8 \\
\hline & Retired & 5 & 3,8 \\
\hline & Total & 130 & 100 \\
\hline
\end{tabular}

Table 2. The frequency and percentage values for the variable called 'do you deal with the physical education lesson of your child?'

\begin{tabular}{lcc}
\hline & $\mathrm{f}$ & $\%$ \\
\hline I do, I praise his/her success & 97 & 74,6 \\
I don't care much even if I do & 29 & 22,3 \\
I don't care & 4 & 3,1 \\
Total & 130 & 100 \\
\hline
\end{tabular}

As is seen in Table 2, 74,6\% of the parents responded as 'I do, I praise his/her success' $22,3 \%$ of the parents answered as 'I don't care even if I do' and 3,1\% of them said that 'I don't care.'

Table 3. The frequency and percentage values for the variable called 'if required, do you procure the materials about the physical education lesson of your child.'

\begin{tabular}{lcc}
\hline & $\mathrm{f}$ & $\%$ \\
\hline I procure by thinking that it is required & 93 & 71,5 \\
Not all of them, I procure what I find necessary & 35 & 26,9 \\
I evaluate as a waste & 2 & 1,5 \\
Total & 100 & 100 \\
\hline
\end{tabular}


According to Table 3, 71,5\% of the parents answered the question called 'If Required, Do You Procure the Materials About the Physical Education Lesson of Your Child' as 'I procure by thinking that it is required' $26,9 \%$ answered this question as 'Not all of them, I procure what I find necessary' and $1,5 \%$ of these attendees responded as 'I evaluate as a waste'.

Table 4. Being compared the answers of the question called 'do you deal with the physical education lesson of your child?' regarding the educational status

\begin{tabular}{lccc}
\hline Educational Status & $\begin{array}{c}\text { I do, I praise his/her } \\
\text { success }\end{array}$ & $\begin{array}{c}\text { I don'care much even } \\
\text { if I do }\end{array}$ & I don't care \\
\hline Literate & $\% 0,8$ & $\% 0$ & $\% 0$ \\
Primary School & $\% 19,2$ & $\% 6,2$ & $\% 2,3$ \\
Secondary Scholl & $\% 17,7$ & $\% 6,9$ & $\% 0$ \\
High Sch. and equiv. & $\% 23,1$ & $\% 5,4$ & $\% 0$ \\
College & $\% 6,9$ & $\% 1,5$ & $\% 0$ \\
Undergraduate & $\% 5,4$ & $\% 2,3$ & $\% 0$ \\
Other & $\% 1,5$ & $\% 0$ & $\% 0,8$ \\
Total & $\% 74,6$ & $\% 22,3$ & $\% 3,1$ \\
\hline
\end{tabular}

As is seen in Table 4, the question called 'Do you deal with the physical education lesson of your child?' is answered as 'I do, I praise his/her success' by $0,8 \%$ of the attendees who are literate, $19,2 \%$ of them who graduated from primary school, $17,7 \%$ of them graduated from the secondary school, $23,1 \%$ graduated from high school and equivalents, $6,9 \%$ of them graduated from college, $5,4 \%$ of them graduated from the undergraduate and finally $1,5 \%$ of them are in the category of others. $2,3 \%$ of the participators who answered as 'I don't care' is primary school graduate, $0,8 \%$ of them graduated from other. $74,6 \%$ of the attendees answered as 'I do, I praise his/her success,' $22,3 \%$ of them said 'I don't care much even if I deal with' and 3,1\% of them said 'I don't care.'

Table 5. Comparing the answers for the question called 'do you deal with the physical education lesson of your child' in terms of the gender

\begin{tabular}{lccc}
\hline Gender & $\begin{array}{r}\text { I do, I praise his/her } \\
\text { success }\end{array}$ & $\begin{array}{c}\text { I don' t care much even } \\
\text { if I deal with }\end{array}$ & I don't care \\
\hline Male & $\% 20,8$ & $\% 6,9$ & $\% 0$ \\
Female & $\% 53,8$ & $\% 15,4$ & $\% 3,1$ \\
Total & $\% 74,6$ & $\% 22,3$ & $\% 3,1$ \\
\hline
\end{tabular}

According to the Table 5, 20,8\% of the participants are the male who answered as 'I do, I praise his/her success, ' and $53,8 \%$ of them are female. $6,9 \%$ of the attendees are male, and $15,4 \%$ of them are the female who responded as 'I don't care much even if I deal with.' While $3,1 \%$ of the participants are the male who returned as 'I don't care,' there is not any man answered like that.

Table 6. Being compared the responses to the article called 'the physical education lesson effects the physical development of the students' regarding the gender variable

\begin{tabular}{cccccc}
\hline \multirow{2}{*}{ Gender } & Strongly Agree & Partly Agree & Barely Agree & Disagree & Total \\
& & & & & \\
\hline Male & $\% 24,6$ & $\% 3,1$ & $\% 0$ & $\% 0$ & $\% 27,7$ \\
Female & $\% 63,1$ & $\% 6,2$ & $\% 2,3$ & $\%, 8$ & $\% 72,3$ \\
Total & $\% 87,7$ & $\% 9,2$ & $\% 2,3$ & $\%, 8$ & $\% 100$ \\
\hline
\end{tabular}


As is seen in Table 6, 24,6\% of the attendees are male, and 63,1\% of them are the female who responded as 'Strongly agree.' $3,1 \%$ of the participants are male, and $6,2 \%$ of them are the female who answered as 'Partly agree.' $2,3 \%$ of the attendees who answered as 'barely agree' are women. $0,08 \%$ of the participants who said 'disagree' are the females. $27,7 \%$ of the participants is male, and $72,3 \%$ of them are women who responded this article called 'The Physical Education Lesson Effects the Physical Development of the Students'.

Table 7. Being compared the answers for the article called 'The Physical Education Lesson Has Impact on the Students to Stand of the Bad Habits' regarding the gender variable

\begin{tabular}{cccccc}
\hline \multirow{2}{*}{ Gender } & Strongly Agree & Partly Agree & Barely Agree & Disagree & Total \\
\hline Male & $\% 17,7$ & $\% 6,9$ & $\% 3,1$ & $\% 0$ & $\% 27,7$ \\
Female & $\% 51,5$ & $\% 13,8$ & $\% 3,1$ & $\% 3,1$ & $\% 72,3$ \\
Total & $\% 69,2$ & $\% 20,8$ & $\% 6,2$ & $\% 3,1$ & $\% 100$ \\
\hline
\end{tabular}

Based on Table 7, 17,7\% of the people who said 'Absolutely agree' for this article is male, and 51,5 of them are the females. $6,9 \%$ of the attendees who said 'Partly agree' are males, and $13,8 \%$ of them are the females. $3,1 \%$ of the attendees are male and 3,1 of them female who responded as 'Barely agree.' 3,1\% of the people who said 'Disagree.' Totally, $27,7 \%$ of the attendees are male, and $72,3 \%$ of the female are females who responded the question.

Table 8. Being compared the Awareness Levels of the Parents About the Benefits of the Physical

Education Lesson in the secondary grade of the primary education schools in terms of the gender

\begin{tabular}{ccccc}
\hline & $\mathrm{n}$ & $\mathrm{X}$ & $\mathrm{ss}$ & $\mathrm{p}$ \\
\hline Female & 94 & 123,1101 & 12,82 & \\
Male & 36 & 122,1017 & 9,92 &, 671 \\
\hline
\end{tabular}

As is seen in Table 8 , there is not determined any discrepancy at $\mathrm{P}>0,05$ level between the awareness levels of the parents regarding the gender variable of T-Test.

\section{Discussion}

$72,3 \%$ of the parents are female, and 27,7 of them are the males who participated in the survey. $6,2 \%$ of them are in the age range of $20-25,6,9 \%$ of them are in the age range of $25-30,35,4 \%$ of them are in 30-35 age range, and 51,5\% of them are 36 age and older. About the degree of the attendees as the parent to the students, 65,4 of them are mothers, 25,4 of them are fathers, $6,2 \%$ of them are brother or sisters, and $3,1 \%$ of these participants are the others. $0,8 \%$ of the parents are literate, $27,7 \%$ of them are primary school graduate, $24,6 \%$ of them are secondary school graduate, $28,5 \%$ of them graduated from the high school and equivalents, $7,7 \%$ of these participants are bachelor's, and finally $2,3 \%$ of them are in the category of others. Under these circumstances, the greater part of the attendees is composed of the parents who are 36 age and older. It is seen when the educational status is evaluated that the general run of the parents graduated from the high school and the equivalents. 6,9\% of these attendees are unemployed, $10 \%$ of them are self-employed, $17,7 \%$ of them are the employee, $4,6 \%$ of them are artisans, $6,2 \%$ of them are soldiers, policemen and officers, $50,8 \%$ are the housewives and 3,8\% are the retired ones. Regarding the question called 'Do You Deal With the Physical Education Lesson of Your Child'; 74,6\% of the parents responded as 'I do, I praise his/her success' $22,3 \%$ of them responded as 'I don't care much even if I deal with' and 3,1\% of these participants answered as 'I don't care' . The answers for the question called 'If Required, Do You Procure the Materials About the Physical Education Lesson of Your Child' as follows; 71,5\% of the parents said 'I 
procure by thinking that it is required' $26,9 \%$ of them said 'Not all of them, I procure what I find necessary' and $1,5 \%$ of them answered as 'I evaluate as a waste'.

$23,1 \%$ of the parents who said that they deal with the physical education lesson constitute the highest rate by mentioning that they graduated from the high school and the equivalents. 53,8\% ratio consists of the female parents who said that they deal with the physical education lesson.

The male attendees got $\bar{X}=123,11$ points concerning the T-Test analysis about the gender variable for the awareness levels of the parents on the benefits of the Physical Education Lesson in the secondary grade of the primary education schools. The female attendees got $\bar{X}=122,10$ points. There is not determined a significant inequality at $\mathrm{P}>0,05$ level between the two gender groups.

24,6 of the parents are male, and $63,1 \%$ of them are the females who think that physical education lesson has positive impacts on the physical development of the students. Totally $87,7 \%$ of the parents expect that the physical training lesson has positive impacts on the physical development of the students. Thampson et al., found in their study in 2001 that the parents from India and America believe that the sports activities have the positive contribution to the physical development of the children [16]. Similarly, Pehlivan confirmed in his study in 200 that the parents perceive that the sports activities are irrevocable for the physical development of the children [13].

$17,7 \%$ of the parents are the males, and $51,5 \%$ of them are the females who think that the physical education lesson has the impact on the students to stand of the bad habits. Entirely $69,2 \%$ of the attendees confirm this positive contribution to sport. Opper et al., mentioned in their research as in the same direction with our results that the rate of smoking and alcohol and substance use are lower of the children who play sport in comparison with the others [10]. Also as it stated in the investigation of Ögel et al. that the parents confirm the positive effect of the sport for keeping the children out of smoking and other harmful substances [12].

Çon et al., mentioned in their study in 1997 that the parents are disposed to be valued the free time by sports activities in the physical education lesson of the secondary grade of the primary education schools [3].

Keskin determined in his investigation in 2006 that the parents who motive their children to the sport are mostly high school graduates by a rate of $33,2 \%$. In our research, the parents who care the physical education lesson are mostly high school graduates as well [6].

According to the scale research [2] about the parents who incredibly attend to the sport of their child that these parents mainly aim the 'physical development' 'athletic skill' and 'competition' [2]. Kilcıgil [7] stated in his research with Turkish families about the family expectation that the first reason for being sent the child to the football club is the desire of the child, the second reason is to provide financial gain and the third one is not to be any traffic risk. According to the study [13], the 'skill development' and 'competition' are placed near the top of the participation motives of the children [14]. It is found in the study of Colchico et al., [1] that the girls who attend to physical activity after the school feel themselves worthwhile and healthy. Moreover, reported that there is an increment in the social skill of children who attend to the physical activity after the school $[13,15]$.

Since the free times of the children increased since the early of the 1950 s, the parents also enhanced the number of the sports activities organized for children. After the Second World War, there occurred a severe increase in the sports programs organized for the children and the Youngs. Before these developments, the girls were being raised to be a good mother in the home environment while the boys were more active in sports. After the 1970s and 1980s, the girls and boys were given the chances by the same ratios in schools and some sections of the society, and the girls became successful as much as the boys. 


\section{Conclusion and suggestions}

The purpose of this study is to reveal the awareness level of the parents about the benefits of the physical education lesson in the secondary grade of the primary education schools. 94 female and 36 male parents from Şehit Ümit Balkan Secondary School attended to the survey.

In terms of the gender variable, there is not determined a significant difference at $\mathrm{P}>0,05$ in between the awareness levels of the parents about the benefits of the physical training lessons.

$87,7 \%$ of the parents think that the physical education teaching has powerful effects on the physical development of the children. $69,2 \%$ of them confirm that this lesson keeps their kids out of the bad habits.

The male participators got $\overline{\mathrm{X}}=123,11$ points as a result of the statistical calculations. The female attendees got $\bar{X}=122,10$ points. The awareness level of both two groups about the benefits of the physical education lesson is found as high.

The physical education teachers and the school management should provide the children and parents to be more conscious by telling them the benefits of the sport and the physical education lesson.

The physical education and sports activities should be organized in schools, and the support of the families must be provided.

There should be conducted works for raising the awareness of the parents about the integrity of the physical education lesson with the other lessons. The parents should be advised for not to isolate their children from the sport because of the other lessons.

It should be efforted for being encouraged the children for sport in the free times by the parents. Thus, the children can be reintroduced to society by improving physically and socially

\section{References}

1. Colchico, K., Zybert, P., \& Basch, C. E. (2000). Effects of after-school physical activity on fitness, fatness, and cognitive self-perceptions: a pilot study among urban, minority adolescent girls. American Journal of Public Health, 90(6), 977.

2. Çepikkurt, F. (2005). Psychological benefits of extreme familial involvement in children's sports: A scale research. Mersin University, Department of Physical Education and Sports of Health Sciences Institute, Master Thesis, (49).

3. Çon, M. (1997). The effect of primary and secondary education institutions on the spore orientations of elite sportsmen. Gazi University Journal of Physical Education and Sports Sciences. 2(1), 41-53.

4. Hergüner, G, Ondokuz Mayıs University Journal of Education Faculty 'The Role and the importance of the Family in motiving the child to sports', Samsun, 1991.

5. Hergüner, G. (1992). Education-Sport Relationship. Ondokuz Mayıs University Journal of Education Faculty, 7(1), 63-66.

6. Keskin, V. (2006). The expectations of the parents who motives their children to the sport. (Published Graduate Thesis). Afyon: Kocatepe University

7. Kilcigil, E. (2003). The reasons and expectations of the families when their child play sport and their socio-economic status. Gazi University High school of Physical Education and Sports, Physical Education and Social Areas Congress in Sports, 214-221.

8. Kuter, M. (2012).Values Education Through Physical Education and Sports. Uludağ University Journal of Education and Humanities: Theory and Practice (Vol): 3 Say1 (No): 6 (Fall), 75-94

9. Larson, C.A. (1970). Curriculum Foundation and Standarts for Physical Education, Englewood Cliffs, New Jersey.

10. Opper, E., Worth, A., Bös, K. (2005). Kinderfitness-kindergesundheit. Bundesgesundheitsbl Gesundheitsforsch Gesundheitsschutz. 48(1), 854-862. 
11. Öğel, K(2005). 'What is Awareness'. http://www.ogelk.net/makale/62-herkes-icinfarkindalik-kabullenme-farkindalik-nedir.html. Access date: 02.05.2016.

12. Ögel, K. Çorapçığlu, A., Sır, A., Tamar M., Tot Ş., Doğan O., et al., (2004). Tobacco, alcohol and substance use prevalence in primary and secondary education in 9 Provinces. Journal of Turkish Psychiatry, 15(2), 112-118.

13. Pehlivan Z.(2009) Expectations of families for children participating in sports, Behavioral changes observed in children and obstacles for the participation in sport, Sportmeter Physical Education and Journal of Sports Sciences, VII (2) 69-76

14. Pehlivan, Z. (2009). Expectations of families for children participating in sports, Behavioral changes observed in children and obstacles for the participation in sport. Journal of Physical Education and Sports Sciences. 7(2), 69-76.

15. Shephard, R. J. (1995). Physical activity, health, and well-being at different life stages. Research quarterly for exercise and sport, 66(4), 298-302.

16. Thompson, J. L., Davis, S. M., Gittelsohn, J., Going, S., Becenti, A., Metcalfe, L., Stone, E., Harnack, L., Ring, K. (2001). Patterns of physical activity among American Indian children: An assesment of barriers and support. Journal of Community Health. 26(6), 423-445

17. Yaylac1, F. (1998). Evaluation of primary school physical education course teaching programs. Afyon Kocatepe University Journal of Social Sciences. (1) 